\title{
Widely Welcomed and Supported by the Public: A Report on the Title IX-Related Comments in the U.S. Department of Education's Executive Order 13777 Comment Call
}

Tiffany Buffkin, Nancy Chi Cantalupo, Mariko Cool, \& Amanda Orlando*

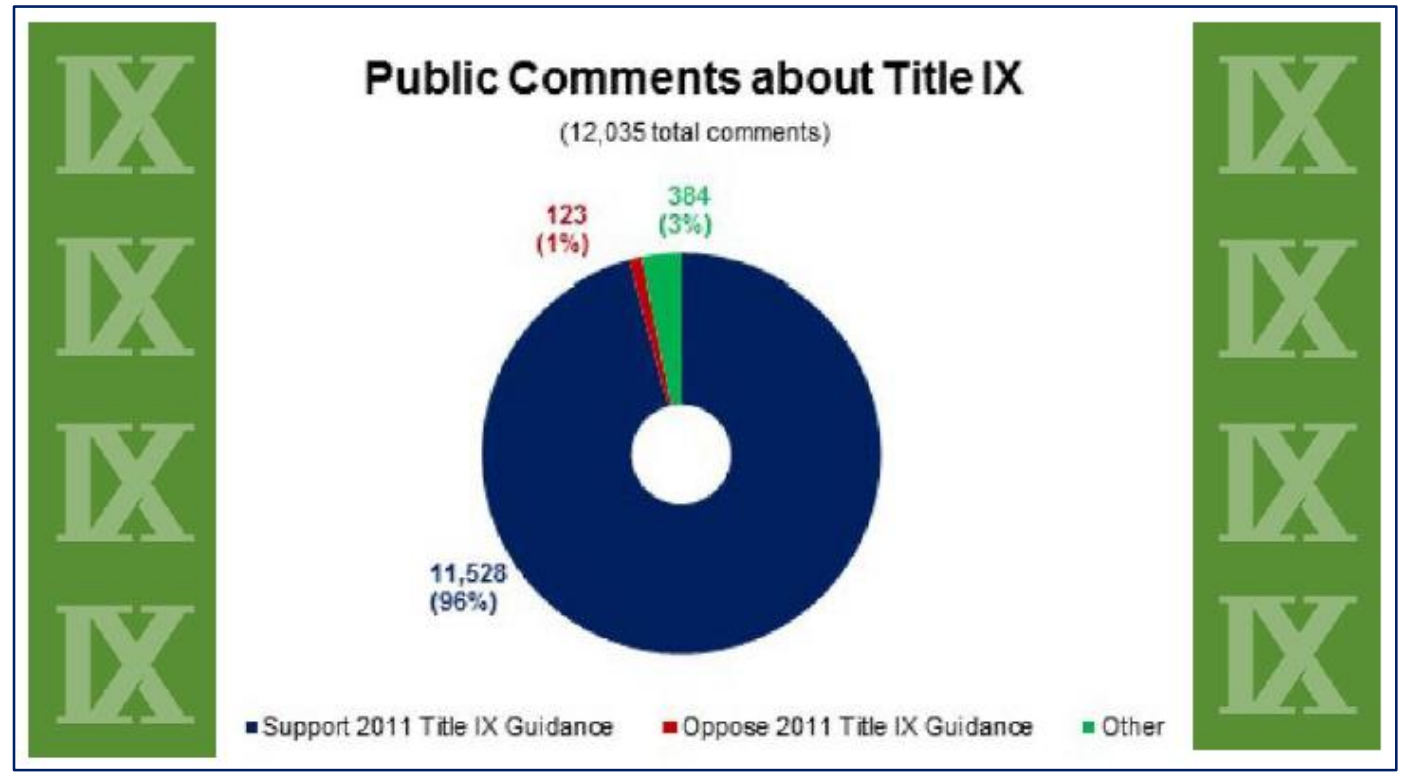

DOI: https://doi.org/10.15779/Z38FN10S49

Tiffany Buffkin and Amanda Orlando conducted research and drafted portions of this report as students at Barry University Dwayne O. Andreas School of Law, under the supervision of Nancy Chi Cantalupo, Assistant Professor of Law. Mariko Cool provided professional drafting, proofreading, and cite-checking for the full report. Our thanks to William C. Kidder for the suggestion that we use a graphic for our core finding, and to Tiana Baheri, Editor-in-Chief of the Berkeley Journal of Gender, Law \& Justice (Vol. 34) and Web-Editor of the California Law Review (Vol. 107), for all of her work in getting this report to publication. All questions about this report may be directed to Nancy Chi Cantalupo at ncantalupo@barry.edu. 


\section{EXECUTIVE SUMMARY}

This report reviews research that coded the content of the 16,376 comments filed with the U.S. Department of Education (ED) in response to ED's call for public comments on Executive Order 13777 (establishing a federal policy to "alleviate unnecessary regulatory burdens"), which closed on September 22, 2017. This research focused on the 12,035 comments that addressed Title IX of the Educational Amendments of 1972 (Title IX) because ED announced, simultaneously with the last weeks of the comment period, that the Obama administration's enforcement of Title IX was a "failed system" that had been "widely criticized," leading ED to rescind the 2011 Dear Colleague Letter (2011 $D C L$ ) guidance document regarding sexual violence in schools. Based on what the 12,035 public comments in fact stated, this report concludes that the system of Title IX enforcement implemented by the Obama administration was in fact widely welcomed and supported by the public, the exact opposite of ED's characterization regarding the extent of public support for this system in September 2017.

Researchers' analysis of the 12,035 public comments addressing Title IX resulted in the following research findings:

- Of the 12,035 public comments addressing Title IX, 99 percent (n: 11,893) of the commenters filed a comment in support of Title IX, with 97 percent of Title IX supporters (n: 11,528) specifically urging ED to uphold the 2011 Dear Colleague Letter: Sexual Violence (2011 DCL). Only one percent (n: 137) filed comments opposing Title IX, of which 90 percent (n: 123) specifically urged that ED rescind the 2011 DCL.

- $\quad 10,363$ comments used the same core language, although 749 of these comments included unique language added by the individual commenter. If all of these 10,363 comments were counted as only one comment (including the 749 with unique individual additions), then, of the resulting 1,673 total comments, 92 percent supported Title IX and only 8 percent opposed Title IX.

- Commenters who described themselves self-identified as attorneys; college/university professors (of multiple disciplines, including law); family members or friends of accused students or student victims/survivors; non-profit professionals; people who work in state Departments of Education, school principals; students accused and/or found responsible of sexually harassing/assaulting other students; teachers; therapists and counselors (including those working in schools and colleges or universities); U.S. veterans; and victims/survivors of sexual violence (both students and nonstudents).

- Of the 11,893 comments that were filed in support of Title IX, 
0.9 percent (n: 104) were posted anonymously. Of the 137 comments that opposed Title IX, 44.5 percent (n: 61) were posted anonymously.

- Two non-profit organizations filed comments that represented individual members of the public who signed petitions or similar joint statements, including one comment representing 38,713 signatories to a petition and sixty comments representing 10,190 individuals in all 50 states, as well as the District of Columbia, U.S. territories, and commenters serving in the military, all in support of Title IX and the $2011 \mathrm{DCL}$.

- When all the individual comments, as well as the petition and jointly-signed comments, are included, 60,796 expressions of support for Title IX were filed by members of the public, in marked contrast to the 137 comments in opposition.

\section{INTRODUCTION}

Title IX is much more than just a law. It is what ensures students due process and support during one of the most challenging times of our lives. It protects us from our abusers. It empowers us. . . I ask you to imagine that, as a young college student of only 19, you were sexually assaulted. What supports would you want in place for yourself? How would you want to be treated? With dignity, respect, and belief, or with blame, shame, and disbelief? I am asking that the Department of Education not roll back vital Title IX protections that relate to campus sexual assault.

-Student Survivor ${ }^{1}$

Without Title IX and the Dear Colleague Letter protections and support thousands of students will be left abandoned and uncared for in the coming school years. It is the duty of the United States Government to protect its people from harm and support them when they are. There is an epidemic of sexual assault victims on our college campuses. Do your duty and protect them by keeping the Dear Colleague Letter and Title IX in[]tact.

-Student Survivor ${ }^{2}$

Title IX of the Education Amendments of 1972, 20 U.S.C. $\$ \$ 1681$ et seq., and its implementing regulations, 34 C.F.R part 106, prohibit discrimination on

1. Student Survivor, Comment ED-2017-OS-0074-11958 (Sept. 13, 2017). Note that this report does not include the names of individual commenters, although it does name organizations when the comment was filed by an organization. Although it is fair to assume that all commenters were aware that their comments and names would be publicly accessible, out of an abundance of caution, this report identifies commenters according to how they self-identified and by their comment number.

2. Student Survivor, Comment ED-2017-OS-0074-12435 (Sept. 14, 2017). 
the basis of sex in education programs or activities operated by recipients of Federal financial assistance. The Office for Civil Rights (OCR) enforces Title IX and seeks to explain the obligations of these entities under Title IX through the issuance of guidance documents and Dear Colleague Letters. In June 2017, the U.S. Department of Education (ED) opened a public comment forum requesting input on the Trump Administration's Executive Order 13777, which established a federal policy to "alleviate unnecessary regulatory burdens." 3 By the end of that August, 10,856 comments had been entered into the system and a few hours clicking through the comments gave the impression that commenters overwhelmingly both commented on Title IX and wrote in support of continuing OCR's robust regulatory enforcement of civil rights in education. ${ }^{4}$

Despite the public comments received by that time and the widespread public opinion they expressed in favor of the Title IX regulatory approach used during the Obama administration, on September 8, two weeks prior to the comment period's closing date of September 21, Secretary of Education Betsy DeVos described the Obama-era Title IX guidance as a "failed system" and announced that ED would be issuing new information about how colleges should handle sexual assault. ${ }^{5}$ Although the vast majority of these comments did not flag this guidance as an example of an "unnecessary" regulation, Secretary DeVos nevertheless acted as if they had done so, and announced plans to write a new federal regulation under Title IX, stating that the public comment period required by the regulatory process would allow the department to "better incorporate insights from various stakeholders into a new regulation."6

The Executive Order 13777 public comment period ended with 16,376 comments submitted, according to a spreadsheet of these comments available on ED's website. ${ }^{7}$ The very next day, ED announced the release of interim guidance in the form of a Questions and Answers on Sexual Misconduct (hereinafter, 2017 Interim Guidance) and rescinded both the 2011 Dear Colleague Letter (2011 DCL) and the 2014 Questions and Answers on Title IX and Sexual Violence (2014 FAQs), both issued by the Obama administration as guidance to schools

3. Evaluation of Existing Regulation: The Proposed Rule Document, (June 22, 2017), https://www.regulations.gov/document?D=ED-2017-OS-0074-0001 [https://perma.cc/JZ7D-AHFP].

4. This was the impression of one of this report's authors when she spent about eight hours looking at comments in late August, but the authors did not start coding comments in a comprehensive fashion until late September.

5. Andrew Kreighbaum, Devos to Replace Obama-Era Sexual Assault Guidelines, INSIDE HIGHER ED (Sept. 8, 2017), https://www.insidehighered.com/news/2017/09/08/devos-says-federaltitle-ix-guidelines-have-'failed'-will-seek-public-input-new [https://perma.cc/7JUU-X3FF].

6. Id.

7. See Evaluation of Existing Regulation, supra note 3. Note that at the time this research was conducted and this report was written, 16,376 comments appeared in the spreadsheet but the total number of comments listed on this website was 16,396. As of the publication date of this report, the total number of comments had changed to 16,489 , with the excel spreadsheet showing 16,467 . 
on how to comply with Title IX in cases of sexual harassment and violence. ${ }^{8}$ This announcement characterized the 2011 DCL as being "widely criticized." The authors of this report wanted to know whether this negative characterization was supported by the contents of the comments, so we undertook to read and analyze them to discover what commenters had said.

This report summarizes our findings. The authors read and coded all 16,376 comments submitted by members of the public during the Executive Order 13777 public comment period, with particular focus on those comments dealing with Title IX, the 2011 DCL and the 2014 FAQs because of ED's statements and actions regarding that guidance. We discovered that out of the 12,035 comments that discussed Title IX, an overwhelming 11,893 comments supported Title IX and urged the Department to uphold the 2011 DCL. Only 137 comments-one percent of the Title IX comments-criticized Title IX and an even smaller number, 123 comments, explicitly requested that ED rescind the $2011 \mathrm{DCL}$. In addition, some of the 11,893 pro-Title IX comments were signed by multiple individuals, resulting in a total of 60,796 expressions of support for Title IX by members of the public.

The remainder of this report will first discuss the authors' research methodology and provide a brief history of OCR's enforcement of Title IX with regard to sexual harassment. It will then analyze the themes of the 12,032 comments received in the Executive Order 13777 comment call that addressed ED's enforcement of Title IX.

I.

METHODOLOGY

Two of the authors used the website Regulations.gov to gather the comments. The website allows for an excel sheet to be exported, which was used to ensure all comments were incorporated into our database. Each comment was reviewed and coded by: (1) type of commenter (individual or organization); (2) whether the commenter was anonymous; (3) whether the commenter discussed Title IX; (4) whether the commenter expressed support or lack of support for civil rights in education generally; (5) whether the commenter supported (or not) Title IX specifically; (6) whether the commenter supported (or not) the 2011 $D C L$; and (7) whether the commenter supported (or not) the use of the preponderance of the evidence standard in Title IX proceedings. These two authors also summarized in their database the specific content of each comment, so as to be able to provide more specific details about noteworthy comments. Coding each of the 16,376 comments and entering them into the database required approximately seven weeks for two authors to complete, with each

8. Department of Education Issues New Interim guidance on Campus Sexual Misconduct, U.S. DEP'T OF EDUC. (Sept. 22, 2017), https://www.ed.gov/news/press-releases/department-educationissues-new-interim-guidance-campus-sexual-misconduct [https://perma.cc/SE8D-26WK].

9. Id. 
author dedicating ten to fifteen hours per week to the project, requiring at least 140-210 hours total, the equivalent of 19-28 full-time working days (of 7.5 hours per workday), to complete the process.

II.

\section{A BRIEF HISTORY OF TITLE IX ENFORCEMENT WITH REGARD TO SEXUAL HARASSMENT}

Title IX of the Education Amendments of 1972 is a federal civil rights law that prohibits discrimination on the basis of sex in any education program or activity that receives federal funding. Originally, Title IX was most commonly used to combat discrimination against women involved in college athletic programs, but, beginning in the 1990s, Title IX was increasingly interpreted by OCR and the courts to protect students from sexual harassment, including sexual assault as a severe form of sexual harassment. ${ }^{10}$ Sexual harassment and violence interferes with students' right to receive an education free from discrimination. ${ }^{11}$ The Title IX obligations placed on schools also apply to gender-based harassment - or acts of aggression, intimidation, or hostility based on sex or sexstereotyping, if the harassment limits the student's ability to participate in, or benefit from, the educational program. ${ }^{12}$

Title IX was inspired by the successful passing of Title VII of the Civil Rights Act of 1964, which addressed discrimination in employment based on race, religion, sex and national origin in the scope of employment, and public accommodation. ${ }^{13}$ Three years after President Nixon signed Title IX into law in 1972, the Office for Civil Rights of the Department of Health, Education, and Welfare issued regulations under Title IX. In order to comply with Title IX, the 1975 regulations require schools to adopt and publish grievance procedures that provide for prompt and equitable resolution of complaints, ${ }^{14}$ as well as to designate at least one employee as the Title IX coordinator to oversee compliance with Title IX and investigate any complaints of sex discrimination. ${ }^{15}$

Fourteen years before the 2011 DCL, the OCR published SEXUAL HARASSMENT GUIDANCE: HARASSMENT OF STUDENTS BY SCHOOL EMPLOYEES, OTHER STUdENTS, OR THIRD PARTIES (1997 GUIDANCE). ${ }^{16}$ In this guidance,

10. See U.S. DEP'T OF EdUC. OfFICE For Civil Rights, REVISEd SEXUAl HaRASSMENT GUIDANCE: HARASSMENT OF STUDENTS BY STUDENTS BY SCHOOL EMPLOYEES, OTHER STUDENTS, OR THIRD PARTIES 28 n.20 (2001), http://www2.ed.gov/about/offices/list/ocr/docs/shguide.pdf [https://perma.cc/VE3T-25YM] [hereinafter REVISED GUIDANCE].

11. Id. at ii.

12. Id. at 3 .

13. Title IX: A Sea Change in Gender Equity in Education, https://www2.ed.gov/pubs/TitleIX/part3.html [https://perma.cc/T88G-4BA2].

14. 34 C.F.R. $\$ 106.8$ (b) (emphasis added).

15. See id. $\$ 106.8(\mathrm{a})$.

16. See generally, U.S. DEP'T OF EDUC. OfFICE FOR Civil RightS, SEXUAL HARASSMENT GUIDANCE: HARASSMENT OF STUDENTS BY SCHOOL EMPLOYEES, OTHER STUDENTS, OR THIRD 
OCR reconfirmed that schools are required by Title IX to adopt and publish grievance procedures that provide for prompt and equitable resolution of sex discrimination complaints, including complaints of sexual harassment. ${ }^{17}$ This guidance identified several relevant elements OCR would evaluate when determining whether a school's grievance procedures were prompt and equitable, including whether the procedures provided for: notice to students, parents, and employees of the procedure; application of the procedure to complaints alleging harassment carried out by employees, other students, or third parties; adequate, reliable, and impartial investigation of complaints, including the opportunity to present witnesses and evidence; designated and reasonably prompt timeframes for major stages of the complaint process; notice to the parties of the outcome; and an assurance that the school will take steps to prevent recurrence of any harassment and correct its discriminatory effects. ${ }^{18}$ The 1997 GUIDANCE required that while the specific steps taken to investigate might vary in each case, each investigation must be prompt, thorough, and impartial in order to comply with Title IX. ${ }^{19}$

In 2001 the OCR issued the REVISED SEXUAL HARASSMENT GuIDANCE: HARASSMENT OF STUDENTS BY SCHOOL EMPLOYEES, OTHER STUDENTS, OR THIRD PARTIES (REVISED GuIDANCE). ${ }^{20}$ This guidance was issued in response to two Supreme Court decisions regarding sexual harassment: Gebser v. Lago Vista Independent School District, 524 U.S. 274 (1998), and Davis v. Monroe County Board of Education, 526 U.S. 629 (1999). Other than the clarification that Gebser and Davis only apply to private lawsuits, the REVISED GUIDANCE was almost identical to the 1997 GUIDANCE, including with regard to the guidelines on "prompt and equitable grievance procedures." 21

When, in 2010, a series of articles occasioned by a Center for Public Integrity (CPI) report, Sexual Assault on Campus: A Frustrating Search for Justice, ${ }^{22}$ brought increased attention to sexual harassment in education, Assistant Secretary for Civil Rights and head of OCR, Russlynn Ali, stated: "We will use all of the tools at our disposal ... to ensure that women are free from sexual violence." 23 Ali subsequently held true to her promise. In April of 2011, she issued a Dear Colleague Letter to schools across the nation. Like all Dear

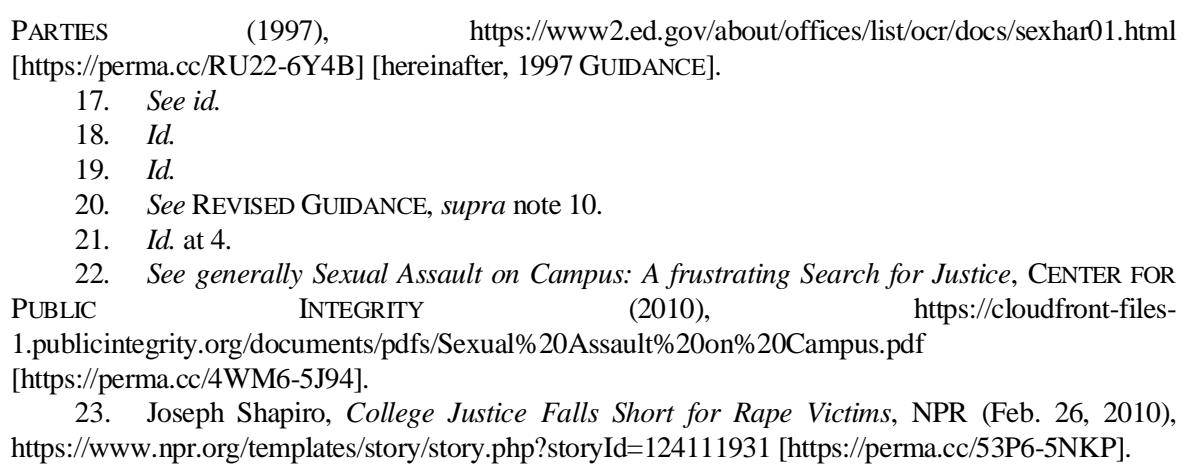

23. Joseph Shapiro, College Justice Falls Short for Rape Victims, NPR (Feb. 26, 2010), https://www.npr.org/templates/story/story.php?storyId=124111931 [https://perma.cc/53P6-5NKP]. 
Colleague Letters, the 2011 DCL was designed to assist schools in meeting the obligations required under Title IX, and its implementing regulations. ${ }^{24}$ As OCR has explained, Dear Colleague Letters and other guidance documents do not add additional obligations to those already required by law. ${ }^{25}$ Instead, by providing information and examples regarding how OCR evaluates whether a school is in compliance with Title IX or another civil rights law, guidance documents seek to explain OCR's requirements so as to help universities, schools, and school districts understand what their existing obligations are under federal law. ${ }^{26}$ In addition, OCR's DCLs aim to inform members of the public about their rights under the laws that ED enforces.

Within this tradition, the 2011 DCL made more concrete several aspects of the 1975 regulations' requirement, reiterated by the 1997 GUIDANCE and the REVISED GUIDANCE, that schools use "prompt and equitable" grievance procedures. ${ }^{27}$ For instance, the 2011 DCL made clear that OCR considered equitable grievance procedures to use a preponderance of the evidence standard, the standard of proof established for violations of civil rights law. ${ }^{28}$ In keeping with the purpose of DCLs generally, OCR gave examples of instances, dating back to 1995, where OCR had interpreted "equitable" to include use of a preponderance of the evidence standard. ${ }^{29}$ In addition, the 2011 DCL specified that as part of providing equitable procedures, a school should provide equal opportunities for both parties to present evidence or produce witnesses. ${ }^{30}$ It also specified that if a school provides an opportunity for appeal of the findings or remedies, it must do so for the accused and complainant, ${ }^{31}$ and if a school allows an attorney to be present at any stage of the hearing, it must do so equally for both parties. ${ }^{32}$ Lastly, the 2011 DCL made its interpretation of the 1975 regulations' and the REVISED GUIDANCE's use of "equitable" more concrete by discouraging schools from allowing parties in a Title IX grievance proceeding to

24. See Letter from Catherine E. Lhamon, Assistant Secretary for Civil Rights, Office for Civil Rights, U.S. Dep't of Educ., to Colleague 2, 12-13 (Oct. 21, 2014), https://www2.ed.gov/about/offices/list/ocr/letters/colleague-bullying-201410.pdf

[https://perma.cc/TY66-DKL6] [hereinafter DCL on Responding to Bullying of Students with Disabilities]; Letter from Seth M. Galanter, Acting Assistant Secretary for Civil Rights, Office for Civil Rights, U.S. Dep't of Educ., to Colleague 2 n.4 (Jan. 25, 2013), https://www2.ed.gov/about/offices/list/ocr/letters/colleague-201301-504.pdf [https://perma.cc/PJD5$\mathrm{YHQH}$ ] [hereinafter DCL on Students with Disabilities in Extracurricular Activities].

25. DCL on Students with Disabilities in Extracurricular Activities, supra note 24, at 2 n.4.

26. Id.; DCL on Responding to Bullying of Students with Disabilities, supra note 24, at 2.

27. Letter from Russlyn Ali, Assistant Secretary for Civil Rights, Office for Civil Rights, U.S. Dep't of Educ., to Colleague (Apr. 4, 2011), http://www2.ed.gov/about/offices/list/ocr/ letters/colleague-201104.pdf [https://perma.cc/4GTX-6BHW] [hereinafter 2011 DCL].

28. Id. at $10-11$.

29. Id. at 10 (discussing 1995 and 2004 OCR investigations where OCR found use of a clear and convincing evidence standard of proof as inequitable and therefore in violation of Title IX).

30. Id. at 9.

31. See id.

32. Id. 
cross-examine or question each other directly. ${ }^{33}$ This clarified the REVISED GUIDANCE's statement that although informal mechanisms for resolving sexual harassment complaints can be used if the parties agree to do so, "OCR has frequently advised schools ... that it is not appropriate for a student who is complaining of harassment to be required to work out the problem directly with the individual alleged to be harassing him or her." ${ }^{34}$ Thus, through the 2011 DCL, OCR made more precise the more general statements of the 1975 regulations and the 1997 and 2001 guidance documents, specifying that OCR considers indirect questioning of one student by another to be equitable, but direct questioning, such as cross-examination, to be an example of requiring a student "to work out the problem directly with the individual alleged to be harassing him or her," which is prohibited by the REVISED GUIDANCE. ${ }^{35}$

In response to the $2011 D C L$, schools asked for so many clarifications that in 2014 OCR released Questions and Answers on Title IX and Sexual Violence (2014 FAQs). ${ }^{36}$ As its name suggests, the 2014 FAQs sought to further clarify the $2011 D C L$ and the REVISED GUIDANCE specifically in response to the many questions schools were asking. Accordingly, the 2014 FAQs explained that while schools have discretion in how to structure their investigative process, the school must give complainants any rights that it gives to alleged harassers in order to be equitable, and reiterated the $2011 \mathrm{DCL}$ 's points regarding the preponderance of the evidence standard and students' equal rights to appeal and to have lawyers. ${ }^{37}$ In addition, the 2014 FAQs added to the list of characteristics found in equitable grievance proceedings a specification that if expert testimony is permitted for one side, it must also be permitted for the other, and that both parties must be notified, in writing, of the outcome of the proceeding. ${ }^{38}$

Finally, in 2015 the Department of Education released the Dear Colleague Letter on Title IX Coordinators (2015 DCL). This letter responded to the widespread lack of awareness by schools and the general public of the 1975 regulations' requirement that schools appoint a Title IX Coordinator. Despite having had 40 years to comply with the 1975 regulation requiring appointment of a Title IX Coordinator, many schools had failed to do so by $2015 .^{39}$ The 2015 $D C L$ therefore sought to address this problem and set out basic requirements for

33. See 2011 DCL, supra note 27 , at 12.

34. See REVISED GUIDANCE, supra note 10, at 21.

35. Id. at 21.

36. Office for Civil Rights, Questions and Answers on Title IX and Sexual Violence, U.S. DEP'T OF EDUC. 2 (Apr. 24, 2014), https://www2.ed.gov/about/offices/list/ocr/docs/qa-201404-title-ix.pdf [hereinafter, 2014 FAQs].

37. Id. at 27.

38. See id.

39. See Kristen Jones, Barriers Curb Reporting on Campus Sexual Assault, CENTER FOR PUBLIC INTEGRITY (Dec. 2, 2009), https://www.publicintegrity.org/2009/12/02/9046/barriers-curbreporting-campus-sexual-assault. 
the qualifications and training of Title IX coordinators. ${ }^{40}$ Like the $2011 D C L$ and the 2014 FAQs, the 2015 DCL was designed to give more specific, concrete guidance to schools on how to comply with the Title IX Coordinator regulation and to inform the public of how Title IX Coordinators are charged with protecting students' Title IX rights. ${ }^{41}$

The 2011 DCL and the 2014 FAQs were rescinded less than 24 hours after the Executive Order 13777 public comment period ended in September 2017, when ED also released interim guidance in the form of a Questions and Answers on Sexual Misconduct (2017 Interim Guidance), as detailed in the Introduction. The $2015 D C L$ was not rescinded and, as of the writing of this report, remains in force.

III.

\section{FINDINGS FROM THE COMMENTS: THE NUMERICAL ANALYSIS}

At the time that the research for this report was conducted, a total of 16,376 comments filed by individuals and organizations in response to the Executive Order 13777 call for public comment appeared in the downloadable spreadsheet available on the Regulations.gov website. Commenters who described themselves self-identified as attorneys; college/university professors (of multiple disciplines, including law); family members or friends of accused students or student victims/survivors; non-profit professionals; people who work in state Departments of Education, school principals; students accused and/or found responsible of sexually harassing/assaulting other students; teachers; therapists and counselors (including those working in schools and colleges or universities); U.S. veterans; and victims/survivors of sexual violence (both students and nonstudents). ${ }^{42}$

Of these, 12,035 comments explicitly address Title IX. Most of the 4,341 other comments discussed the statutes protecting the rights of students with disabilities, the Family Educational Record Privacy Act, and educational funding issues. These 4,341 comments also included comments that were clearly against

40. See Letter from Catherine E. Lhamon, Assistant Secretary for Civil Rights, Office for Civil Rights, U.S. Dep't of Educ., to Colleague 7 (Apr. 24, 2015), https://www2.ed.gov/about/offices/list/ocr/letters/colleague-201504-title-ix-coordinators.pdf.

41. Id. at 5 .

42. Other than when it is quoting a comment, this report generally uses survivor to refer to those who have reported or disclosed in some way that they have experienced harassment, regardless of whether a neutral factfinder has found that person to have been harassed. Where appropriate, it occasionally uses victim as a synonym for survivor, and complainant-survivor to refer to survivors where the context indicates that the survivor has filed a claim, complaint, lawsuit, etc. that accuses a specific person of harassment. Similarly, this report uses accused, either as an adjective or a noun, to designate someone who has been accused of harassing or victimizing someone else, regardless of whether a neutral factfinder has found that person to be responsible for such conduct. Where appropriate, it also uses alleged as a synonym for accused. 
changing OCR's historical approach to enforcement, but were not counted further for this report because they did not explicitly address Title IX. ${ }^{43}$

Out of the 12,035 comments addressing Title IX, 99 percent-11,893 comments - supported Title IX, and 97 percent of these Title IX supporters (n: $11,528)$ specifically urged ED to uphold the 2011 DCL. Less than one percent of the comments supporting Title IX were posted anonymously ( 0.9 percent; $\mathrm{n}$ : 104).

One percent of the 12,035 comments- 137 comments-opposed the Title IX regulations and guidance that had been put in place by the Obama or previous administrations and were still in force during the Executive Order 13777 public comment period. ${ }^{44}$ Out of these comments, 90 percent (n: 123) specifically urged that ED rescind the $2011 D C L$ and 44.5 percent (n: 61) of the comments were posted anonymously.

The same core language was used by 10,363 comments, stating:

All Department of Education civil rights regulations and guidance documents are important and necessary. Far from being burdensome, current [i.e. pre-September 2017] civil rights rules and regulations benefit schools and students by providing a clear framework that, when followed, allow all students an equal opportunity to learn in a safe and welcoming environment regardless of sex, race, color, national origin, disability status, English proficiency, sexual orientation, or gender identity.

I urge the Department to keep in its current [i.e. pre-September 2017] form 34 C.F.R. pts. 1 thru 1299, which include regulations governing the Secretary and the offices for Civil Rights; Elementary and Secondary Education; Special Education and Rehabilitative Services; Career, Technical, and Adult Education; Post-Secondary Education; Educational Research and Improvement; and the National Council on Disability.

I also urge the Department to preserve all current [i.e. pre-September 2017] significant guidance documents, including guidance on sexual, racial, and disability-based harassment (including guidance on sexual violence); access to athletic opportunities; gender equity in career and technical education; single-sex schools; equal access to educational resources; nondiscriminatory school discipline; racial diversity programs; the rights of students with disabilities in charter schools; restraint and seclusion of students with disabilities; and the rights of

43. See, e.g., Individual, Comment ED-2017-OS-0074-15724 (Sept. 29, 2017) ("more evidence that this administration is attempting to destroy children."); Teacher, Comment ED-2017-OS-007416280 (Oct. 4, 2017) ("Keep your hands off this. It would be a disservice to students who benefit from this."); Survivor, Comment ED-2017-OS-0074-15955 (Oct. 2, 2017) (“As a survivor of sexual assault I would ask you to remember that this is an under-reported crime. Do not turn back the progress we have made on this issue.").

44. Note that five comments addressed Title IX but did not take a position for or against it. Therefore, the pro-Title IX comments and the anti-Title IX comments add up to 12,030. 
English language learners. I urge you to keep current [i.e. pre-September 2017] regulations and guidance in place, and to continue enforcing these critical civil rights laws so that all students have an equal opportunity to learn and thrive. ${ }^{45}$

Of the comments using this core language, only twenty-four were anonymous commenters. Most commenters used the core language and included their name and location at the bottom of the comment.

There were 749 comments that contained the comment above in its entirety or in part, then also added language unique to that individual commenter. Some commenters added to their comment with information about their personal experience with the guidance, including explaining why they were using similar language as other commenters. One poster explained that the language was provided by a non-profit organization, but stated "I am including it because it states, more clearly than I can, what needs to be said." 46 Another commenter explained, "The National Women's Law Center has expertise in this issue and I am happy to lean on their legal language. But know that I am passionate about this issue, as is everyone who sends in a letter like this, and we will not be silenced, and we are not going away." ${ }^{47}$ Other comments acknowledged that the comment above would likely have already been seen by DeVos, but urged her to read it again because it was so important. ${ }^{48}$

Many of the commenters added their experience and basis of knowledge for stating how important the pre-September 2017 regulations and guidance are to protecting students. For instance, an educator/administration professional who served in the field of K-adult education posted the core language but also stated, “. . . there is nothing more important than a diverse educational population, void of all forms of discrimination! Protections were put in place prior to this administration, and those must remain unchanged." ${ }^{49}$ Another teacher with over 30 years' experience posted a comment stating "I know first hand our Department of Education civil rights regulations and guidance documents are not burdensome or onerous. I fully support preserving all of our rules and regulations that protect students' civil rights and I respectfully demand you do so as well!" 50 Still another teacher added, "Having spent 30 years as a secondary school teacher I can vouch for the importance and relevance of 34 C.F.R 1-1229." ${ }^{51}$ Other comments stressed that there were reasons for the implementation of these guidance documents, and those reasons have not gone away; ${ }^{52}$ and that the

45. See, e.g., Individual, Comment ED-2017-OS-0074-0793 (Aug. 9, 2017) (emphasis added).

46. Individual, Comment ED-2017-OS-0074-8649 (Aug. 15, 2017).

47. Individual, Comment ED-2017-OS-0074-5923 (Aug. 15, 2017).

48. See, e.g., Teacher, Comment ED-2017-OS-0074-11732 (Sept. 12, 2017).

49. Educator/Administration Professional, Comment ED-2017-OS-0074-5874 (Aug. 14, 2017).

50. Teacher, Comment ED-2017-OS-0074-8582 (Aug. 15, 2017).

51. Teacher, Comment ED-2017-OS-0074-8743 (Aug. 15, 2017).

52. See, e.g., Parent, Comment ED-2017-OS-0074-5905 (Aug. 15, 2017); Parent, Comment ED-2017-OS-0074-8719 (Aug. 15, 2017). 
regulations and guidance remain vital protections.$^{53}$ One commenter added to the standard language by pointing out that in an ideal world, this guidance would be unnecessary, but, because racism and misogyny are rampant, the regulations and guidance are in fact necessary. ${ }^{54}$

Other comments added language voicing concerns about the effect of rescinding any pre-September 2017 regulation or guidance. A teacher posted the following additional language:

As a teacher, I find any attempt to minimize the importance of maintaining equality in the classroom through such regulations and rules to be both despicable and misguided. We owe ALL our students the same opportunities, and the learning experience for all students will be woefully diminished should such regulations and rules be discarded. ${ }^{55}$

Other teachers likewise filed comments that added to the standard language with individualized comments regarding their experience during their career and concerns regarding what public schools would become if the regulations and guidance were rescinded. One teacher stated:

I taught in public schools for over 23 years. I've literally thrown my body into fights that were racially motivated, usually football players in groups attacking a single non-white kid. I've held crying and fearful kids who were abused on campus: verbally, mentally, and physically. For these kids, for their families and friends, you must keep all rules and regulations in place. And for us, their teachers and administrators, help us keep peace and teach all people are created equal. To take away these rules and regulations is to open the gates to bigotry, discrimination, and more verbal, mental, and physical abuse. ${ }^{56}$

Comments also were posted by parents who voiced concerns for their daughters' safety if the pre-September 2017 guidance were not preserved. For instance:

I am the parent of a middle school daughter and a son in high school. I also work for a non-profit organization that works with girls of color from low-income communities in California. I can assure you from my own experience, and the experience of my children and clients, that sexual harassment is alive and well in our public schools. A 2011 study by the American Association of University Women found that nearly 6 in 10 girls in grades 7-12 had been sexually harassed at school. It is even worse for students who are lesbian, gay or transgender. Harassment is a serious issue: As the Department of Education has noted, harassment can have severe emotional and educational consequences for students, including anxiety, low self-esteem, difficulty concentrating, absenteeism, and poor academic performance. It "undermines the health

53. Parent, Comment ED-2017-OS-0074-8675 (Aug. 15, 2017).

54. Parent, Comment ED-2017-OS-0074-5905 (Aug. 15, 2017).

55. Teacher, Comment ED-2017-OS-0074-8521 (Aug. 15, 2017).

56. Teacher, Comment ED-2017-OS-0074-8655 (Aug. 15, 2017). 
of its victims and creates conditions that negatively affect learning." (DOE guidance 2010). Moreover, the frequency of sexual harassment is not reflected in the number of official reports. Many students report that their schools regularly ignore or discount harassment and minimize complaints. Few schools create the kind of environment in which students feel safe reporting harassment, or know they will be taken seriously.

The Department of Education has a responsibility to enforce Title IX and protect students from discrimination and harassment. Protecting civil rights is not a burdensome regulation- it is a fundamental duty of our democratic government. Now is NOT the time to roll back DOE guidance or funding for enforcement. Our children and families deserve better. ${ }^{57}$

Another parent added her personal experience, urging the department not to rescind, but to strengthen, the guidance, as sexual assault leaves survivors in such a vulnerable situation:

My daughter was sexually assaulted twice within the first two months of her freshman year at university. This along with a 2 year violent intimate partner relationship with a "boyfriend" at the same university [and she] finally had to drop out due to depression, anxiety and PTSD. My daughter, even with ALL CIVIL RIGHTS LAWS INTACT, did not get justice or enough help from her university to stay in school. Her only way to heal at this moment is to work and it is a daily struggle. Since my daughter wanted to be a high school English teacher and may never graduate from any university in the U.S. so she can teach, I URGE you to do better by students that must rely on these laws to continue to stay in university and graduate. My daughter was a straight A student. What a loss to this nation of an excellent teacher. Please do not let any more loss occur. Uphold the civil rights laws under the Department of Education and when possible STRENGTHEN them. ${ }^{58}$

Still other commenters added language to the standard language to explain that discrimination is a real issue, including an attorney who pointed out that the rules currently in place "have helped many young girls in particular to become strong and safe because they have the backing of their teachers and principals." 59 Another noted that one way to combat the threat of discrimination is through "departmental guidance that helps schools understand how to fulfill their Title IX civil rights obligations to students." 60 This comment also explained that such guidance is supported by both legal precedent and public opinion:

A recent National Women's Law Center poll found that $87 \%$ of voters supported the guidance for sexual assault, and an even wider margin

57. Parent, Comment ED-2017-OS-0074-5910 (Aug. 15, 2017).

58. Parent, Comment ED-2017-OS-0074-8694 (Aug. 15, 2017).

59. Individual, Comment ED-2017-OS-0074-11501 (Sept. 11, 2017).

60. Individual, Comment ED-2017-OS-0074-8747 (Aug. 15, 2017). 
(94\%) agree with the guidelines for when a student should be disciplined Although I am a white woman, from my participation in anti-racism groups and my reading, it is my understanding that discrimination is a real and serious issue that can interfere with a student's ability to learn and feel safe or welcome in school. I have heard from many girls and women who have been deprived of their basic right to equal educational opportunities: Black girls are unfairly suspended for vague, subjective reasons or for wearing braids or natural hairstyles; pregnant students are told to choose between the health of their unborn child or repeating the semester; institutions ignore the threat a sexual assailant poses to other students on campus. When schools don't take their civil rights duties seriously, they create a hostile environment that pushes kids out of the classroom year after year. And although courts can provide a remedy for some, others may not be able to afford the financial or emotional toll of litigation. ${ }^{61}$

Survivors of severe sexual harassment like sexual assault and rape added language to the standard comment in support of keeping the pre-September 2017 guidance, emphasizing the importance of the then-current guidance and explaining the severe effects of trauma that they faced in the aftermath of the harassment. ${ }^{62}$ One, a retired occupational therapist, added a comment about her personal experience when there were no protections in place for survivors:

I am a woman whose father took private, non-disclosed intimate license, while I was in elementary school. I didn't reveal this to anyone that might've helped me. . . .No one at school was ready in 1967 to assist me for the effects of my father's assaults. ... Girls like me, regardless of ethnicity, national origin or unseen disability need assistance to have equal opportunity to learn, to feel safe and welcomed. Suicidal depression hung over me. Help students like me learn that living and thriving are possible. Ms. DeVos has shown herself to be very callous about schoolgirls like I was. It is not burdensome, but worthwhile, to support and assist students like I was. ${ }^{63}$

Another survivor added a comment discussing why regulations and guidance are so important for survivors to feel safe and confident:

On a very personal note, I was molested for many years as a child at home. I confided in my 6th grade teacher who informed the authorities and my parents. I still suffer from the trauma and I am 38 years old. If it weren't for the trust I felt in school to confide in my teacher, I know for certain, I would have committed suicide as a teenager. You are making a mistake and I beg you to preserve these imperative regulations

61. Id.

62. See e.g., Parent, ED-2017-OS-0074-11524 (Sept. 12, 2017); Retired Occupational Therapist, Comment ED-2017-OS-0074-8737 (Aug. 15, 2017); Survivor, Comment ED-2017-OS0074-10487 (Aug. 29, 2017).

63. Retired Occupational Therapist, Comment ED-2017-OS-0074-8737 (Aug. 15, 2017). 
and guidance. ${ }^{64}$

Those who work with survivors also submitted comments explaining why it is important to continue to dedicate efforts to enforcement of Title IX. For example, a commenter who served for fifteen years at the California Department of Education and the California Postsecondary Education Commission added this language:

I can assure you that even in a state as committed to equity and opportunity as California, there is still much work to be done. The department's rules and regulations and the helpful Guidance Letters provided are critical tools to educate people in our schools about how they can assure truly equal education to all. Removing these tools sets this work back decades.

What the Department of Education really needs to do is provide more opportunities and resources to educate the people who educate our children on what their responsibilities are to assuring equity across all dimensions of student identity. That is what the public education system should be about. There are experts around the country, models for teacher and administrator training, and printed resources that can expand the understanding of equity and help educators create truly equitable schools.

Assuring equity is not "burdensome." Not having these rules and regulations fails our students and the people who educate them. It fails the huge system of public education that is the underpinning of our democracy. Most of all, it puts the burden on the students whose education is damaged or destroyed by inequitable schools. ${ }^{65}$

Finally, some commenters' additions to the standard language expressed that they were angered over ED trying to weaken investigation of college campus rape. ${ }^{66}$ These comments added language that, for example, urged the Department to keep the then-current guidance since it provided for a fair and equitable school environment ${ }^{67}$ and warned that rescinding it would send the message that the administration is "standing up for the aggressors[,] not the victim[s]." 68

The 749 comments that added unique language to the core text used in these 10,363 comments especially demonstrate that all 10,363 of these comments were filed for serious, weighty reasons that deserve equally serious, weighty consideration. Nevertheless, if ED decided to count all 10,363 comments as one comment because they contained the same core language (and ignored that 749 commenters added unique language), the comment count would still result in 1,673 comments addressing Title IX, with 1,531 of those comments supporting

64. Survivor, Comment ED-2017-OS-0074-11524 (Sept. 12, 2017). $15,2017)$.

65. Retired state Department of Education employee, Comment ED-2017-OS-0074-8735 (Aug.

66. See, e.g., Relative, Comment ED-2017-OS-0074-6620 (Aug. 15, 2017).

67. Parent, Comment ED-2017-OS-0074-9785 (Aug. 29, 2017).

68. Parent, Comment ED-2017-OS-0074-9798 (Aug. 29, 2017). 
Title IX. This would still result in 92 percent of the total comments addressing Title IX favoring continuing the historical and Obama-era guidance, and only eight percent being opposed to that guidance. ${ }^{69}$ If the 749 comments that added unique language were counted as individual comments, then there would be 2,422 comments addressing Title IX, and 2,280 (94\%) supporting Title IX. Thus, regardless of how ED counts the comments, the percentage of commenters supporting rescission is in the single-digits.

In addition to the 11,893 individuals who showed their support for the existing Title IX enforcement scheme through individual comments, many comments from organizations were posted on behalf of thousands of individuals and supporters. For instance, the American Association of University Women (AAUW) posted sixty comments in support of Title IX. These comments included 10,190 signatures from people residing in all 50 states, as well as signatures of people representing the District of Columbia, U.S. territories, and military personnel..$^{70}$ Each of these sixty comments contained a letter addressed to Secretary DeVos which stated:

Title IX of the Education Amendments of 1972 is the federal law that prohibits sex discrimination in education. This vital law affects all areas of education, including: recruitment, admissions and housing; pregnant and parenting students; science, technology, engineering, and math (STEM); sexual harassment and assault; and athletics. It requires recipients of federal education funding to evaluate their current policies and practices, adopt and publish a policy against sex discrimination, and implement grievance procedures providing for prompt and equitable resolution of student and employee discrimination complaints.

I join with the American Association of University Women (AAUW) in urging the Department of Education to protect Title IX, preserve all of its current [i.e., pre-September 2017] regulations and guidance, and fully enforce the law.

Unfortunately, many students still do not have access to an equitable education free from sex discrimination. AAUW research found that 56 percent of girls and 40 percent of boys in grades 7-12 face sexual harassment. Of that number, 87 percent said it had a negative effect on them. In addition, girls have 1.2 million fewer chances to play sports in high school than boys. Less than two-thirds of African American and Hispanic girls play sports, while more than three-quarters of Caucasian girls do. Pregnant and parenting students are often steered toward separate, less rigorous schools. Just 12 percent of engineers are women, and the number of women in computing has fallen from 35 percent in 1990 to just 26 percent today.

69. The five comments that did not take a position on Title IX account for $0.2 \%$ of this count, a percentage so small it disappears when the percentages are rounded up.

70. See, e.g., American Association of University Women, Comment ED-2017-OS-007416358 (Oct. 16, 2017). 
The Office for Civil Rights (OCR) at the U.S. Department of Education has a long history of ensuring technical assistance and fair enforcement of federal civil rights laws, including Title IX. For decades, students and advocates have called on OCR to enforce Title IX, and its long-standing regulations and guidance.

As Secretary of Education, you have the power to address this critical civil rights issue and help make schools safer and more equitable for all students. I join with AAUW in urging the Department of Education to keep in place current [i.e., pre-September 2017] Title IX guidance and regulations and fully enforce the law. ${ }^{71}$

Similarly, the National Women's Law Center (NWLC) posted a comment with 38,713 signatures in support of Title IX and the $2011 \mathrm{DCL} \cdot{ }^{72}$ The following statement was included in the comment urging ED not to rescind the 2011 DCL:

Experiencing sexual assault is devastating enough. Students who suffer it shouldn't have to face the double burden of recovering from violence and a lifetime of diminished educational, social, and economic opportunities.

Yet for too many student survivors, that's the devastating reality when their schools fail to take even basic steps to ensure their safety or accommodate their physical and emotional recovery.

Without clear, enforceable standards for how to investigate and address complaints of sexual assault, many survivors end up being pushed out of school, while their attackers face no consequences and remain free to harm additional people. These institutional failures effectively punish survivors for other people's violence against them, while making campuses more dangerous for everyone.

As Secretary of Education, you have the power to address this critical civil rights issue and help make campuses safer for everyone. We urge you to listen to survivors, and publicly commit to preserve and enforce the 2011 Sexual Violence Guidance and help eradicate campus sexual assault. ${ }^{73}$

Thus, the 99 percent of individual commenters and the 11,893 comments they filed in support of Title IX could represent a significant underestimate of the level of public support for Title IX. When both the individual comments and the organization-aggregated comments are taken into account, members of the

71. Id. Note that these 60 comments are different from the comment also posted by the American Association of University Women (AAUW) Interim Vice President of Public Policy \& Government Relations at infra note 93. These comments were one-page comments in support of all the Title IX's guidance then in place, and contained as attachments the above language thousands of times with individual signatures after each comment. The comment at infra note 93 was a four-page document discussing in detail and listing all guidance that it was supporting; including the $2011 \mathrm{DCL}$, the Clery Act, and guidance regarding student loans.

72. National Women's Law Center, Comment ED-2017-OS-0074-16357 (Oct. 16, 2017).

73. Id. 
public filed 60,796 expressions of support for Title IX, compared to 137 comments that criticized Title IX.

IV.

\section{FINDINGS FROM THE COMMENTS: COMMENT THEMES}

This section of the report focuses on the 1,670 comments written and filed by members of the public individually, in which several themes emerged, including (1) that OCR's enforcement of Title IX prior to September 2017 was needed and welcomed, (2) that OCR's Title IX guidance, including the 2011 $D C L$ and 2014 FAQs, were consistent over time and historically, and (3) that "due" and fair process is vital in Title IX investigations of sexual harassment allegations. This section will discuss each of these themes.

\section{A. Comments Expressing the Need for and Welcomed Nature of the Obama-Era Title IX Guidance}

I am writing as a higher education professional dedicated to campus safety and community well-being. I am acting independent of my role and institution. I write with grave concern.

I have witnessed the positive impact of Title IX guidance from OCR across the country. Survivors previously frightened to come forward have braved the silence and shared their stories. Campuses have become safer as perpetrators of violence, which research informs are likely re-perpetrators of violence, are sanctioned and, when appropriate, removed from campuses. While the system is not perfect and institutions have some ongoing questions and challenges, the overall shift has been positive.

-Higher Education Professional ${ }^{74}$

For years, sexual offenders were getting away with assaulting other students on campus. If we don't hold offenders accountable, the scourge of sexual violence on college campuses will continue unabated. The 2011 DCL is a critical guidance document to schools to help them achieve compliance with Title IX's civil rights provisions.

-Law Professor ${ }^{75}$

Comments supporting the need for Title IX regulations and guidance addressed their impact on (1) individual survivors and (2) educational institutions and society at large. Some comments also addressed the impact of the guidance on accused students.

74. School Administrator, Comment ED-2017-OS-0074-16272 (Oct. 4, 2017).

75. Law Professor, Comment ED-2017-OS-0074-16365 (Oct. 16, 2017). 


\section{Impact on Survivors}

Survivors, their loved ones, and various organizations filed comments describing the positive impact of the pre-September 2017 Title IX guidance for survivors. These comments focused on how the 2011 DCL assisted survivors in understanding the rights and remedies they were guaranteed by Title IX, discussed the difficulties many survivors faced in accessing their Title IX rights prior to the $2011 D C L$, and urged ED not to rescind the Obama-era guidance, as rescission would harm survivors, especially survivors who are already particularly vulnerable, such as those with a disability or who are lesbian, gay, bisexual, transgender, and queer (LGBTQ) or women of color.

Several survivors discussed how the 2011 DCL "helped [them] understand [their] rights under Title IX" after they were assaulted. ${ }^{76}$ For instance, one survivor described the restorative resources made available by Title IX and the 2011 DCL:

I was raped on my college campus two years ago this Halloween. The mental damage that being raped did to me was something I wish upon no one. I felt alone and did not know what to do. I turned to drugs to try and forget my mental pain. After a few months I came upon campus resources that changed my life. After learning about and reaching out to services provided at my school due to the Dear Colleague Letter and Title IX I was able to receive academic accommodations, counseling, support from fellow survivors and was able to report my incident. ${ }^{77}$

In contrast, another survivor discussed how not knowing about the Title IXmandated supports on the survivor's campus prevented her from reporting the rape she suffered and getting any of the assistance that Title IX offered. She called for the preservation of the existing approach to Title IX and increased publicity of Title IX rights to students:

Like literally countless survivors of sexual assault, I never reported my rape. I had no idea that there were structures other than the criminal justice system in place that could have helped me. Not only will dangerous ploys to change an approach to Title IX decrease reporting, they will stop the important progress in making sure Title IX is applied justly. We need to make sure more survivors know about the support that Title IX can offer. A preponderance of evidence (which is the standard in civil court cases) is a thoroughly appropriate method for handling Title IX cases. It is up to individual institutions to see justice through, but they MUST have sufficient support to do so. ${ }^{78}$

A friend of two survivors shared the perspective of students at her undergraduate institution regarding the difference the 2011 DCL made to the effectiveness of investigations of allegations of sexual violence:

\footnotetext{
76. See, e.g., Student Survivor, Comment ED-2017-OS-0074-16173 (Oct. 3, 2017).

77. Student Survivor, Comment ED-2017-OS-0074-12435 (Sept. 14, 2017).

78. Student Survivor, Comment ED-2017-OS-0074-11828 (Sept. 12, 2017).
} 
When I was an undergrad, two of my friends were raped by the same man. When they learned that it was the same man, they chose to report to the Title IX Coordinator in the spring of 2014. While the process was frustrating and difficult at times for both of them, and the appeals board found that there was not enough evidence to find him responsible in one of the cases, it found there was enough evidence in the other case to find him responsible, and he was expelled. Based on my conversations with older students, it is hard for me to imagine this happening before the 2011 Dear Colleague Letter and the outpouring of student activism on my campus and nationally around this issue. His expulsion meant that my friends did not have to share the campus with their rapist. ${ }^{79}$

These sentiments were echoed in several comments from scholars who study sexual violence and organizations with expertise on these issues. A law professor explained that victims of sexual harassment can experience "serious, discriminatory harms" as a result of being victimized, and characterized the issuance of the $2011 D C L$ as having been "compelled by these acute needs of students." ${ }^{80}$ Likewise, the organization End Rape On Campus, which engages with thousands of students every year, mostly survivors of sexual violence, noted that rescinding any civil rights protections will disproportionately hurt sexual assault survivors and students who are already at a greater risk of being sexual assaulted such as women of color, students with disabilities, and students in the LGBTQ community. ${ }^{81}$ The Human Rights Campaign (HRC), the nation's largest organization working to achieve equal rights for the LGBTQ community, agreed, posting a comment on behalf of the campaign's three million members and supporters nationwide, ${ }^{82}$ acknowledging the disheartening statistics of sexual harassment on college campuses as reported by the Association of American Universities:

$11.7 \%$ of students reported experiencing "nonconsensual penetration or sexual tou[c]hing by force or incapacitation" since enrolling in higher education. $23.1 \%$ of undergraduates and $8.8 \%$ of graduate students identifying as female reported experiencing sexual violence. Those identifying as transgender, gender-nonconforming, questioning, or something not otherwise listed also face a significant risk, as $24.1 \%$ of undergraduates and $15.5 \%$ of graduate students reported similar experiences. $5.4 \%$ of undergraduates identifying as male reported experiencing sexual violence, as did $2.2 \%$ of graduate students. ${ }^{83}$

The HRC concluded from this data that the continued threat of sexual assault on college campuses does not suggest that the critical 2011 guidance should be

79. Individual, Comment ED-2017-OS-0074-15888 (Oct. 2, 2017).

80. Law Professor, Comment ED-2017-OS-0074-0074 (Aug. 3, 2017).

81. End Rape on Campus, Comment ED-2017-OS-0074-16153 (Oct. 3, 2017).

82. Human Rights Campaign, Comment ED-2017-OS-0074-13163 (Sept. 22, 2017).

83. Id. 
rescinded. Rather, it commented, the statistics "should stand as an indication to this Department that it must increase support for these students." 84

\section{Impact on Accused Students}

Commenters also addressed the impact of Title IX and the 2011 DCL on accused students, both negative and positive impacts. For instance, one mother posted a comment urging the Department to rescind 2011 DCL because she believed her son had been falsely accused, and that the school her son attended, West Point, "deliberately destroyed" her son to protect themselves and to appease the accuser's family. ${ }^{85}$ She stated that her family "has spent the last six years trying to repair the damage" that resulted from her son being accused of sexual assault. ${ }^{86}$

In contrast, a comment supporting Title IX and the $2011 \mathrm{DCL}$ posted by Men Stopping Violence suggested that greater accountability for sexual violence will have positive effects on accused students' future lives. Thus, the organization urged that rescinding the $2011 D C L$ would be detrimental to both survivors and the accused:

Rescinding or revising any [pre-September 2017] guidance and regulations - including the 2011 Dear Colleague Letter - is not in the best interests of survivors. Furthermore, rescinding or revising any [preSeptember 2017] guidance and regulations is not in the best interests of men who violate women because it would undermine the accountability they need to have meaningful and respectful relationships with women. ${ }^{87}$

\section{Positive Impact on Institutions and Society at Large}

Many comments came from educational or other professionals who have personally witnessed the positive effects both inside and outside educational institutions of Title IX and the 2011 DCL. A forty-year educator described how she has seen the $2011 D C L$ and other guidance documents take hold, creating institutions and learning environments that make it possible for every student to thrive, regardless of their sex, race color, sexual orientation, gender identity, national origin or disability status. ${ }^{88}$ The director of a rape crisis program in Pennsylvania wrote that since the 2011 DCL was issued by Obama Administration, those involved in the program have "seen incredible strides forward on the four college campuses that our agency is affiliated with in regards to the fair and equitable treatment of all parties involved in Title IX

84. Id.

85. Parent, Comment ED-2017-OS-0074-9764 (Aug. 29, 2017).

86. Id.

87. Men Stopping Violence, Comment ED-2017-OS-0074-15723 (Sept. 29, 2017).

88. Educator, Comment ED-2017-OS-0074-14843 (Sept. 27, 2017). 
proceedings." 89 A law professor shared insight into her experience over the past twenty years that has affirmed that the $2011 D C L$ is "deeply needed and deeply appreciated by those trying to end the epidemic of sexual harassment and genderbased violence occurring on our campuses." 90 She described how, if anything, many higher education professionals had been disappointed that the 2011 DCL was not "more detailed and extensive, and OCR's response to this dissatisfaction led to [the] issuance of the 2014 Questions and Answers." 91

A former ED Assistant Secretary for Civil Rights pointed out that making the major changes that Secretary DeVos announced on September 8, 2017 would also distract OCR's attention away from providing schools with assistance that would help them deal with "increased reporting of sexual harassment and assault." 92 Thus, rescinding the 2011 DCL and 2014 FAQs would rob schools of "a useful framework to develop their own institutions' procedures and systems... [because o]n many campuses there is evidence that this OCR guidance has helped generate a better understanding of how to create safer and more equitable school climates." 93

The American Association of University Women (AAUW) posted a comment on behalf of 170,000 members and supporters of the AAUW urging the Department to protect Title IX by preserving the guidance and regulations in effect at that time, including the $2011 \mathrm{DCL} .{ }^{94}$ In explaining how rescinding the existing Title IX guidance would be detrimental, the AAUW wrote:

Sexual harassment pervades the lives of students. AAUW research found that 56 percent of girls and 40 percent of boys in grades 7-12 face sexual harassment. Of that number, 87 percent said it had a negative effect on them.... Removing protections and guidelines provided by regulation and guidance would be detrimental to women and girls. They would lose out on the full value of an education, an impact that follows them through lives and impacts our economy and society as a whole. ${ }^{95}$

\section{B. Comments Addressing Consistency of the 2011 DCL with OCR's Historical Enforcement of Title IX and OCR's Enforcement of All the Civil Rights Statutes in its Jurisdiction}

While the DOE can and should continue to hold schools accountable to provide fair processes, changing substantially the evidentiary standard would signify a retreat on its important enforcement role. Moreover, it

89. Director of Rape Crisis Center, Comment ED-2017-OS-0074-15720 (Sept. 29, 2017).

90. Law Professor, Comment ED-2017-OS-0074-0063 (July 28, 2017) (note that commenter co-authored this report).

91. Id.

92. Civil Rights Attorney, Comment ED-2017-OS-0074-15738 (Sept. 29, 2017).

93. Id.

94. American Association of University Women, Comment ED-2017-OS-0074-16026 (Oct. 2, 2017).

95. American Association of University Women, Comment ED-2017-OS-0074-16026 (Oct. 2, 2017). 
would be legally inconsistent with civil rights and anti-discrimination laws, and thus would lead to unnecessary and avoidable excessive litigation.

- Law Professor ${ }^{96}$

Attorneys, professors, school administrators, and teachers filed comments pointing out that the clarifications provided in the 2011 DCL were consistent both with the historical approach to implementing Title IX requirements and with investigations required by all the other civil rights statutes enforced by ED. Therefore, these commenters regarded rescission of the 2011 DCL and 2014 FAQs to constitute a major policy shift away from this historical approach.

A lawyer who has litigated Title IX cases, worked on Title IX policy, and conducted Title IX education programs for over twenty years noted that the claim by Secretary DeVos that ED's 2011 DCL changed the law or took schools by surprise was incorrect. ${ }^{97}$ The attorney explained that the 2011 DCL summarized "existing law and existing best practices" and particularly addressed objections regarding the preponderance of the evidence standard (discussed more below), stating that "preponderance of the evidence has been the standard of proof for ALL civil rights matters and ALL civil legal matters since the beginning of our legal system." 98

Several law professors - many of whom (including one of this report's coauthors) were among 110 law professors who signed a White Paper supporting the use of the preponderance of the evidence standard ${ }^{99}$ - focused on the consistency of the $2011 D C L$, particularly its clarification that the preponderance of the evidence standard is the appropriate standard of proof, not only with OCR's historical enforcement of Title IX but also with its enforcement of other civil rights laws under its jurisdiction. One of these law professors, who was formerly a university administrator, summarized the clear legal support for the then-extant regulatory approach as it was reiterated by OCR's 2011 clarification. ${ }^{100}$ She explained that, because the "OCR's regulatory activities during 2011-16 were responsive to the needs of higher education institutions and the higher education professionals who are primarily responsible for ensuring that their institutions comply with Title IX, this regulatory approach should be continued in the future." ${ }^{\prime 101}$ A different law professor pointed out that the 2011

96. Law Professor, Comment ED-2017-OS-0074-16365 (Oct. 16, 2017).

97. Civil Rights Attorney, Comment ED-2017-OS-0074-16074 (Oct. 2, 2017).

98. Id.

99. See Katherine Baker, Deborah L. Brake, Nancy Chi Cantalupo, et al., Title IX \& the Preponderance of the Evidence: A White Paper (2017), http://www.feministlawprofessors.com/wpcontent/uploads/2017/07/Title-IX-Preponderance-White-Paper-signed-7.18.17-2.pdf [https://perma.cc/UB9X-ZKVL].

100. Law Professor, Comment ED-2017-OS-0074-0063 (July 28, 2017) (note that commenter co-authored this report).

101. Id. 
$D C L$ 's clarifications are fully consistent with the civil rights approach to discriminatory harassment and the rules in the vast majority of other disciplinary proceedings. ${ }^{102}$ Furthermore, this professor noted that the 2011 DCL was consistent with the majority of schools' existing best practices for student discipline since the majority of schools has already adopted the preponderance of the evidence approach years before 2011. ${ }^{103}$

This law professor also warned that, had OCR not adopted the $2011 \mathrm{DCL}$, "it would have engaged in a dangerous kind of exceptionalism for only sexual violence and its victims, the majority of whom are women and girls." 104 A third law professor, who founded a Gender Violence Program at her law school, expressed a similar concern, explaining that a clear and convincing standard of proof would "be confusing to schools [and] would create a discriminatory system for sexual violence cases when preponderance of the evidence is the standard for all other civil rights cases." 105 Moreover, she pointed out that the problems for accused students that Secretary DeVos cited in her announcement on September 8, 2017 were not caused by compliance with unfair regulations, but were instead examples of Title IX violations of the 2011 DCL. ${ }^{106}$

In addition, this law professor noted, requiring a clear and convincing standard of proof "would create an unnecessary regulatory morass rather than streamlining regulation as requested in this evaluation of existing regulations." 107 The former OCR Assistant Secretary agreed, pointing out that, although the original purpose of the Executive Order 13777's call for public comments was to reduce the number of federal regulations, Secretary DeVos's September 8, 2017 announcement expressed intentions would actually add to federal Title IX regulation instead of reducing it. ${ }^{108}$

\section{Comments Addressing Due Process Concerns}

Title IX guidance documents regarding sexual harassment, dating back to the 1997 GUIDANCE, particularly the 2011 DCL, let schools know they should provide "due process" for both accused students and for survivors. ${ }^{109}$ What constitutes due process under civil rights versus criminal laws is different and this difference has led to much controversy over which type of due process ought to be used when schools investigate sexual harassment and assault; therefore, many of the individual comments addressed the issue of what kinds of procedures constitute due process and/or fair process. These comments included

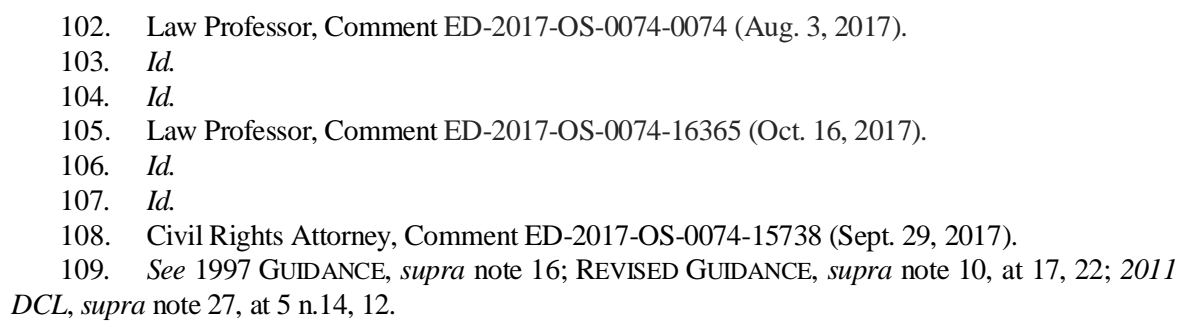


those complaining that the $2011 \mathrm{DCL}$ violated the rights of accused students, those charging that approaches contrary to the $2011 D C L$ would violate the due process rights of survivors, and those stating that the 2011 DCL provided equal due process to both survivors and accused students.

\section{Due Process for Accused Students}

[T]he balance has shifted from neglecting victims to railroading innocent accused students.

-Co-author of book on campus sexual assault \& due process ${ }^{110}$

Sexual assault is a criminal offense and should have the same standard of due process. This is why schools have NO BUSINESS holding hearings to determine responsibility for sexual assault... The most frequently occurring cases are where the man and woman agreed to have sex, but then for some reason she "wasn't really into it" and the next thing you know the man has an assault charge against him.

-Anonymous ${ }^{111}$

Of the comments against Title IX, many asked the Department to rescind the 2011 Dear Colleague Letter out of a concern for the due process rights of the accused, particularly arguing that the preponderance of the evidence standard was too low of a standard ${ }^{112}$ and that the accused should have the right of direct confrontation. ${ }^{113}$ A mother posted a comment saying that certain due process rights were not provided to her son. In her comment she stressed that the interpretation of the $2011 \mathrm{DCL}$ is unacceptable because it allows a "process of adjudication that has been designed, institutionalized, and enforced in a manner that legitimizes the presumption that the accused is guilty." 114

This mother also urged that there should be serious consequences for false accusations. ${ }^{115}$ Other commenters also expressed concern about false accusations, which they characterize as a serious problem, citing to certain prominent cases such as the Duke lacrosse case as evidence of the frequency of false accusations. ${ }^{116} \mathrm{~A}$ second mother mentioned that she has consulted with over 110 parents who say their children were wrongfully accused. ${ }^{117}$

110. Individual, Comment ED-2017-OS-0074-0050 (July 14, 2017).

111. Individual, Comment ED-2017-OS-0074-13251 (Oct. 16, 2017).

112. See, e.g., Professor, Comment ED-2017-OS-0074-8578 (Aug. 15, 2017).

113. See, e.g., Law Professor, Comment ED-2017-OS-0074-9604 (Aug. 29, 2017).

114. Parent, Comment ED-2017-OS-0074-10377 (Aug. 29, 2017).

115. Id.

116. See NCFM Carolinas, Comment ED-2017-OS-0074-9282 (Aug. 16, 2017).

117. Parent, Comment ED-2017-OS-0074-9367 (Oct. 26, 2017). 
Anti-Title IX commenters often linked their concern about false accusations with specific procedures encouraged by the $2011 \mathrm{DCL}$. For instance, some commenters objected to the 2011 DCL's guidance to schools not to allow direct cross-examination of each student by the other, suggesting that the lack of direct cross examination makes such proceedings biased against the accused student. For instance, one commenter objected to the 2011 DCL's guidance on cross-examination, stating that "the woman just has her friends be her witness (though in reality there were no witnesses to the actual encounter) and her friends simply tell the investigator whatever the complainant told them to say". ${ }^{118}$

Similarly, many commenters also stated that a "clear and convincing evidence" standard should be used when adjudicating such "life-altering cases." 119 Commenters who argued that the stricter "clear and convincing" standard was appropriate for accusations of sexual harassment were concerned about the burden and stigma that result from an accused student being found responsible and sanctioned with "life-crushing" expulsion or suspension. ${ }^{120}$

These commenters also objected to what they felt was too wide of a definition of prohibited sexual conduct, ranging from a "harmless" cat-call to forcible rape. ${ }^{121}$ While making similar arguments, a contributing editor who has co-authored, with a professor of history, two books regarding what the authors identify as due process violations in campus sexual violence cases, faults the Obama-era OCR guidance for not reducing the rate of campus sexual violence, guidance which this commenter charges has channeled "real" victims away from the police so rapists avoid prison. ${ }^{122}$

This co-author submitted a comment that included an excerpt from one of his co-authored books. In addition to echoing many of the points other commenters made regarding false accusations and the life-changing consequences of expulsion or suspension for sexual violence, the comment objects to the costs to universities and "families of innocent students" of "federally prescribed procedures - all of which increase the likelihood of guilty findings - to determine whether accused students are guilty (often called 'responsible') or innocent," particularly the staff required "to police students' sexual activities." 123 Other anti-Title IX commenters agreed with this point about cost, ${ }^{124}$ including one commenter who questioned the statistics on campus sexual assault, which the commenter suggested were deliberately overblown to justify university staffing levels. ${ }^{125}$

118. Individual, Comment ED-2017-OS-0074-13251 (Sept. 22, 2017).

119. See, e.g., NCFM Carolinas, Comment ED-2017-OS-0074-9282 (Aug. 16, 2017).

120. See Individual, Comment ED-2017-OS-0074-13251 (Oct. 16, 2017); Individual, Comment ED-2017-OS-0074-12703 (Sept. 20, 2017).

121. See Parent, Comment ED-2017-OS-0074-9367 (Aug. 17, 2017).

122. Individual, Comment ED-2017-OS-0074-0050 (July 14, 2017).

123. Id.

124. See Parent, Comment ED-2017-OS-0074-0049 (July 14, 2017).

125. Parent, Comment ED-2017-OS-0074-9367 (Aug. 17, 2017). 
A final common concern of those who registered their opposition to Title IX was that Title IX has caused a shift towards victims' rights that has gone too far. One mother of an accused student stated that "Sexual assault is horrific and cannot be tolerated, but the DCL has done much more harm than good." 126 Similarly, four law professors who opposed the 2011 DCL attached a memorandum arguing that "[t]hough OCR did not require schools to treat accused students unfairly in the investigation and adjudication process, its tactics put pressure on them to stack the system so as to favor alleged victims over those they accuse." 127 The memorandum gives such examples as "some colleges and universities fail[ing] even to give students the complaint against them, or notice of the factual basis of charges, the evidence gathered ...,"128 although such examples appear to violate the due process requirements laid out in the 2011 $D C L$, suggesting that these law professors may agree with the assertion by proTitle IX commenters that the similar examples of due process violations cited by Secretary DeVos on September 8, 2017, were in fact violations of Title IX and the $2011 D C L$.

\section{Due Process for Complainants (Survivors)}

The university gave me hope once they found him guilty of raping me but the sanctions were a year of suspension and a slap in my face... The conversation should remain about the survivors who have lost scholarships, opportunities, and the basic right to a fair education, not rapist college men who negatively change the lives of their victims and continue to take steps forward.

$$
\text { -Survivor }^{129}
$$

If you are of the belief that police and the judicial system do better by survivors than schools can, read the literature.

$$
\text { -Anonymous }{ }^{130}
$$

Whereas the focus of the anti-Title IX commenters was on due process for accused students, many commenters who supported Title IX asked ED to retain the $2011 D C L$ out of a concern for the due process rights of survivors. Commenters pointed to both the historical and current erecting of extra procedural hurdles for survivors to overcome in sexual violence cases and expressed their concern that rescinding the 2011 DCL would leave survivors once again with inequitably fewer procedural rights. An education consultant

126. Id.

127. Law Professors, Comment ED-2017-OS-0074-9604 (Aug. 29, 2017).

128. Id.

129. Student Survivor, CommentED-2017-OS-0074-15071 (Sept. 27, 2017).

130. Student, Comment ED-2017-OS-0074-12696 (Sept. 20, 2017). 
wrote that " $[t]$ he system has not failed the "falsely accused;" it has and continues to fail survivors. ... Leveling the playing field does not bestow extra privileges on survivors, it attempts to provide survivors with the same support and rights that alleged perpetrators have enjoyed forever. ${ }^{131}$

Several commenters expressed concern about the procedural exceptionalism traditionally used by the law and legal institutions in sexual violence cases, particularly the poor treatment of victims by law enforcement. ${ }^{132}$ Commenters pointed out that the preponderance standard is used in all other discrimination cases, yet other victims are not treated in the skeptical or hostile way that sexual assault survivors are, despite the low occurrence of false accusations. ${ }^{133}$ A commenter endorsed the statement by the National Alliance to End Sexual Violence that "[v]ictims can experience serious, discriminatory harms, and the issuance of the 2011 Dear Colleague letter was compelled by the acute needs of students. . . Indeed, if OCR had adopted a different approach, it would have engaged in a dangerous kind of exceptionalism for only sexual violence and its victims, the majority of whom are women and girls." 134

Although none of the commenting survivors or survivor advocacy groups raised such a concern, the four law professors who commented in opposition of the $2011 D C L$ argued that the $2011 D C L$ was unfair to the survivor as well as the accused. ${ }^{135}$ They argued that "an exclusively disciplinary or punitive approach needlessly deprives victims of options that may benefit them in the pursuit of equal educational opportunity" and suggested mediation or restorative justice approaches as alternatives. ${ }^{136}$ In contrast, many survivors spoke approvingly of the $2011 \mathrm{DCL}$ 's adoption of the preponderance of the evidence standard as providing due process to both victims and accused. One survivor described the preponderance standard as "a thoroughly appropriate method for handling Title IX cases." 137 A law professor echoed these remarks, stating that the preponderance of the evidence is the correct standard and is "essential if we expect schools to be able to discipline what is well documented as the routine expropriation of sex from women by college men." 138

A sexual assault prevention educator in New York, explained that both parties - victim and perpetrator - have a right to be heard and to safely receive an education. "The Dear Colleague letter simply opened the door for survivors to know that their voices would be heard... Too many perpetrators of sexual

131. Education Consultant, Comment ED-2017-OS-0074-12248 (Sept. 14, 2017).

132. See, e.g., Student, Comment ED-2017-OS-0074-12696 (Sept. 20, 2017).

133. See e.g., Individual, Comment ED-2017-OS-0074-15251 (Sept. 27, 2017).

134. Individual, Comment ED-2017-OS-0074-9840 (Aug. 29, 2017).

135. Law Professors, Comment ED-2017-OS-0074-9604 (Aug. 29, 2017).

136. Id.

137. Student Survivor, Comment ED-2017-OS-0074-11828 (Sept. 12, 2017).

138. Law Professor, Comment ED-2017-OS-0074-0107 (Aug. 7, 2017). 
violence destroy a fellow student's right to an education. Rolling back the Dear Colleague letter will simply continue that cycle." 139

\section{Equal Due Process for Both Complainant-Survivors and Accused Students}

First, I affirm the preponderance of evidence as the appropriate evidentiary standard in disciplinary proceedings. Considering the most extreme potential penalty to be imposed (never to exceed anything beyond expulsion), a standard beyond preponderance of evidence is not proportional to the potential sanctions.

-Higher Education Professional ${ }^{140}$

A final group of comments on due process argued that the 2011 DCL and other Title IX guidance documents, issued by the Obama administration and previous administrations, offer due process equally to both accused students and complainant-survivors. These comments either explicitly countered statements about due process advanced by the anti-Title IX commenters or spoke about characteristics of Title IX and the $2011 D C L$ that gave equal due process rights to each student.

Several comments explicitly countering statements about due process by the anti-Title IX commenters addressed the issues of false reporting, and one commenter even provided research from several different sources that concluded the prevalence of false reporting is between two percent and ten percent. ${ }^{141}$ This comment pointed out that the prevalence of false reporting is low, and the real issue is that the majority of sexual assault cases are never reported because many survivors face scrutiny and barriers when they do speak out. ${ }^{142}$

Other comments also questioned claims about equating being investigated or found responsible for sexual harassment with the trauma of being sexually violated or the consequences of conviction by a criminal court. A law professor who joined the White Paper on Title IX and the preponderance of the evidence standard explained that, as the 2011 DCL made clear, college disciplinary proceedings are not meant to function as criminal courts of law because what is at stake is not criminal consequences, but rather the "presumption that one went through college without doing anything wrong ... Expulsion need not and often should not follow a finding of culpability, nor need any man found responsible believe that "his life is over." "143 Similarly, a friend of multiple survivors wrote:

I also know multiple students at my undergrad (both male and female)

139. Sexual Assault Prevention Educator, Comment ED-2017-OS-0074-12244 (Sept. 14, 2017).

140. Higher Education Professional, Comment ED-2017-OS-0074-16272 (Oct. 4, 2017).

141. See Individual, Comment ED-2017-OS-0074-12797 (Sept. 20, 2017).

142. See id.

143. Law Professor, Comment ED-2017-OS-0074-0107 (Aug. 7, 2017). 
who were accused of sexual assault or harassment. Other than the man who raped two of my friends, none of those students were suspended or expelled. While I know it was a stressful process to be accused and be investigated by your school, comparing what they went through to the trauma of being assaulted is absurd. Stress is not trauma." 144

Other commenters pointed out why the $2011 D C L$ does not allow, much less require, that an accused student's due process rights be violated. A survivor of campus sexual assault posted a comment explaining:

With the clear notification of charges, the right to have a hearing, and the right to appeal the charges a second time, I see no lack of due process ... the "worst case" scenario is expulsion. Universities are given great liberty to choose their students, which is why potential students must submit applications. If a university can easily reject a potential student, it is not unreasonable for it to expel a student who is considered more likely than not to have committed sexual misconduct. ${ }^{145}$

The Human Rights Campaign agreed, stating:

Contrary to the claims made by those who oppose this guidance, the guidance does not impose a "guilty until proven innocent" regime that falls unfairly on those who are accused of sexual harassment and sexual violence. Rather, the guidance requires the Title IX coordinators, investigators, and adjudicators to be thoroughly trained and impartial in order to have a truly equitable process. ${ }^{146}$

Finally, a law professor pointed out that the 2011 DCL was essential to the safety needs of all students, explaining "Fair process, as provided for in the 2011 $D C L \ldots$ mandates equal treatment for both sides with an emphasis on victim safety, public safety, and offender accountability." ${ }^{147}$ Similarly, a survivor of sexual violence talked about how the 2011 DCL empowered her to protect her own rights and could be used in the same way by accused students. After explaining that she was able to point to the exact portions of the $2011 \mathrm{DCL}$ that her university was failing to comply with in order to access a fair process, she stated, "perhaps most important about the 2011 Dear Colleague Letter is that my rapist also would have been able to do just as I did if he felt my university's failures were harming him as they were harming me."148

\section{CONCLUSION}

I want the Department of Education to uphold the 2011 Dear Colleague letter and other Title IX protections because I want to ensure that I am

144. Individual, Comment ED-2017-OS-0074-15888 (Oct. 2, 2017).

145. Student, Comment ED-2017-OS-0074-12679 (Sept. 20, 2017).

146. Human Rights Campaign, Comment ED-2017-OS-0074-13163 (Sept. 22, 2017).

147. Law Professor, Comment ED-2017-OS-0074-16365 (Oct. 16, 2017).

148. Student Survivor, Comment ED-2017-OS-0074-16173 (Oct. 3, 2017). 
safe when I go to college.

The comments that were submitted in response to Executive Order 13777 do not support the assertions in Secretary DeVos's speech on September 8, 2017 (two weeks before the comment period closed) or ED's subsequent announcement rescinding the 2011 and 2014 guidance documents (the day after the comment period closed). Those statements called the Obama administration's Office for Civil Rights enforcement of Title IX a "failed system" that had been "widely criticized." Further, Secretary DeVos promised to "better incorporate insights from various stakeholders into a new regulation." Contrary to these statements, the overwhelming majority of the public's comments submitted to ED prior to and during the same time period supported the Obama-era Office for Civil Rights' enforcement of Title IX.

Of the 12,035 public comments addressing Title IX, 99 percent of the commenters filed a comment in support of Title IX, of which 97 percent urged ED to uphold the $2011 \mathrm{DCL}$, whereas only one percent filed comments opposing Title IX (90 percent of which requested that ED rescind the 2011 DCL). Even if the 10,363 comments that used the same core language were counted as only one comment (including the 749 comments in which the commenter added unique language), 92 percent of the resulting 1,673 comments supported Title IX and the $2011 D C L$ and only 8 percent opposed the $2011 D C L$.

Moreover, the percentage of anonymous comments that opposed Title IX was nearly 30 times the size of the same percentage supporting Title IX. Of the 11,893 comments that were filed in support of Title IX and the 2011 DCL, 1.5 percent were posted anonymously. Of the 137 comments that requested ED rescind the $211 \mathrm{DCL}, 44.5$ percent were posted anonymously.

Non-profit organizations also filed comments, many of which represented individual members of the public who signed petitions or similar joint statements, including 38,713 signatories to a petition in support of Title IX and the $2011 D C L$ and sixty comments filed by the American Association of University Women representing 10,190 individuals. When all the individual comments - as well as the petition and the jointly-signed comments-are factored in, people went on public record 60,796 times supporting historical and Obama-era Office for Civil Rights enforcement of Title IX, including the 2011 $D C L$.

Thus, the Department of Education's statements and actions in September 2017 do not appear to be accurate or based on the evidence that the Department of Education had before taking action on September 8 and 22. Rather than viewing the system of Title IX enforcement implemented pre-September 2017 as a "failed system," 11,893 to 60,796 members of the public took the time to

149. Student, Comment ED-2017-OS-0074-11746 (Sept. 12, 2017). 
inform ED of their support for Title IX and the 2011 DCL, whereas only 137 people did the same in opposition to the $2011 \mathrm{DCL}$. Based on this data, ED appears to have actively ignored evidence of the public's view that, contrary to ED's statements, this enforcement system was widely welcomed, supported and viewed as successful by members of the public. 